Full reference: Bufarwa, I.M., Elamer, A.A., Ntim, C.G. ., \& AlHares, A. (2020) 'Gender Diversity, Corporate Governance and Financial Risk Disclosure in the UK', International Journal of Law and Management, Forthcoming (Accepted $10^{\text {th }}$ February 2020).

\title{
Gender Diversity, Corporate Governance and Financial Risk Disclosure in the UK
}

\author{
Idris M Bufarwa \\ Faculty of Economics and Political Science, University of Benghazi, Libya \\ Email: edrisbo@yahoo.com
}

\begin{abstract}
Ahmed A. Elamer *
Brunel Business School, Brunel University London, Kingston Lane, Uxbridge, London, UB8 3PH

$\mathrm{UK}$; and

Department of Accounting, Faculty of Commerce, Mansoura University, Mansoura, Egypt

Email: ahmed.a.elamer@gmail.com

*Corresponding author

\section{Collins G. Ntim}

Department of Accounting, Centre for Research in Accounting, Accountability and Governance, Southampton Business School, University of Southampton, Southampton, SO17 1BJ, UK

Email: C.G.Ntim@soton.ac.uk
\end{abstract}

\section{Aws AlHares}

Department of Accountancy and Finance, Business School, University of Huddersfield, UK, and Faculty of School of Business Studies, College of the North Atlantic in Qatar, Qatar

Email: aalhares@yahoo.co.uk

*Corresponding author: Brunel Business School, Brunel University London, Kingston Lane, London UB8 3PH, UK, E-mail: ahmed.elamer@brunel.ac.uk or/and ahmed.a.elamer@gmail.com. 


\title{
Gender Diversity, Corporate Governance and Financial Risk Disclosure in the UK
}

\begin{abstract}
Purpose - This study investigates the impact of corporate governance mechanisms on financial risk reporting in the UK.

Design/methodology/approach - The study uses a panel data of 50 non-financial firms belonging to ten industrial sectors listed on the London Stock Exchange in the period 2011-2015. Multivariate regression techniques are used to examine the relationships. Additionally, to alleviate the concern of potential endogeneity, we use two-stage least squares and fixed effect estimators.

Findings - The findings of this study reveal that corporate governance has a significant influence on financial risk disclosure. Specifically, we find that block ownership and board gender diversity have a positive effect on the level of corporate financial risk disclosure. While, there is no significant relationship between board size and corporate financial risk disclosure.
\end{abstract}

Originality/value - This study adds to the emerging body of literature on corporate governance-risk disclosure relationship in UK context using content analysis. The study also highlights that gender diversity enhances financial risk disclosure.

Keywords: Financial risk disclosure, block ownership, gender diversity, board size, corporate governance.

JEL classification: G21, G32, G34, G38, M48 


\section{Introduction}

Over the past two decades, the concept and practice of corporate governance has gradually become the central focus for academics, managers and policymakers (Abor \& Fiador, 2013; Elmagrhia et al., 2018; Katarachia et al., 2018; Fatima et al., 2018; Nyombi, 2018; Stuebs \& Sun, 2015; Srivastava et al., 2018). This can be attributed to the increasing concerns over the rising incidences of corporate fraud as well as fraudulent financial disclosure leading to corporate scandals and the collapse of major firms (Gerged et al., 2018; Luo, 2016). This significant attention given to corporate governance structures and principles in firms indicates that it has a major influence on both policies and strategies and, therefore, the eventual financial performance of these corporations. Without doubt, corporate governance mechanisms in the UK have become stronger in recent years, which can be largely attributed to the development of corporate governance codes from as early as 1992 through to today (Cheffins, 2015). This journey began with the introduction of the Cadbury Code in 1992, which focused on the separation of corporate ownership and control as well as the composition of a corporate board and the set-up of an internal control system (Cheffins, 2015). The Cadbury Code was followed by the Greenbury report in 1995, whose contribution largely focused on the remuneration of corporate directors. The Greenbury report was followed by the Hampel report in 1998, which concentrated on the management of risk in corporate organisations (Elshandidy \& Neri, 2014).

Of particular interest in the UK's corporate governance scene is financial disclosure and accountability. The Cadbury Committee was established in 1991, mainly because of continuing concerns regarding the standards of financial disclosure as well as accountability due to an earlier generation of corporate scandals such as the BCCI, Maxwell, and Polly Peck (Elzahar \& Hussainey, 2012). In 2003, the Higgs report was subsequently introduced, designed to provide guidance to corporate organisations with regard to the important role of external directors as well as the audit committee. Recent economic changes, as well as the emergence of high profile financial and economic failures over the past decade, have reminded management boards, heads of corporate organisations and regulators of the need for efficient corporate governance and financial risk disclosure (FRD) approaches (Luo, 2016). In the UK, these financial and economic troubles have addressed the need to understand and fine-tune the relationship between corporate governance, risk management and corporate FRD, which a number of research studies have sought to investigate (Alnabsha et al., 2018; Elamer \& Benyazid, 2018; Elamer et al., 2017). The case of the Equitable Life Assurance Society, a UKbased insurance firm, which failed to provide its investors with the proper financial risk reports 
leading to the loss of millions of pounds of investors' money, demonstrates the critical importance of risk management and in particular FRD within the UK corporate environment (Cheffins, 2015).

There is a need to unearth how corporate governance mechanisms influence FRD in the UK corporate context. Previous studies have only attempted to focus on the agency theory as well as the corporate board monitoring role as a context of just concentrating on corporate governance (Luo, 2016). However, this study proposes to employ a multi-theoretical framework, where the study looks into essential and relevant theories, such as agency, shareholder, stakeholder. Also, the majority of the past studies on corporate governance and FRD were conducted in the period prior to the year 2010, which means there can be a research gap in the period after the recovery of the UK's economy. During the period between 2010 and 2016, numerous events, as well as changes, have taken place with regard to corporate governance, not just at country level but also at global level, which influences matters within the UK's corporate sector. It is well known that the presence of a smart governance system within corporate organisations can provide the relevant strategy designed to help such corporations in overcoming economic as well as financial challenges, such as the case of the 2007/2008 global financial crisis (Trinh et al., 2015). Therefore, the period after the global financial crisis proves to be essential with regard to conducting this study in order to further examine the nature and influence of corporate governance mechanisms in the UK's corporate sector.

Therefore, this study contributes to the current research by measuring the level of FRD and the determinants of risk disclosure and how corporate governance mechanisms may enhance FRD in developed countries such as the UK in recent years after the 2007/2008 global financial crisis.

The remainder of the study is organised as follows. The following section reviews corporate governance reforms and financial risk reporting challenges within the UK context. The next sections discuss the theoretical framework for financial risk reporting, review the empirical literature on FRDs and corporate governance, outline the research design, report the empirical results, and provide a conclusion. 


\section{Theoretical literature}

The motivation and variations in FRD, as well as the impact of CG on FRD, can generally be explained by a number of theories, including agency and stakeholder theories. These theories tend to place emphasis on different aspects of FRD and governance phenomena, as explained below, and to this extent, they are not mutually exclusive with each particular theoretical perspective being limited in its ability to fully explain the impact of CG on the level of FRD (Elamer et al., 2019; Ntim et al., 2013; Ntim \& Soobaroyen, 2013).

First, agency theory can be used to explain FRD, especially when it comes to explaining information asymmetry and uncertainty between shareholders and management (Fama \& Jensen, 1983; Jensen \& Meckling, 1976). Better governance structures could enable investors to deal more effectively with risk diversification, portfolio investment decision-making and reducing investors' uncertainty by alleviating information asymmetry between insiders and outsiders via enhancing financial risk disclosure (Ntim et al., 2013). Second, from a stakeholder theory perspective, in the current complex business environment, firms may choose to ameliorate financial risk disclosure as differentiating characteristic; to send significant signals to the different stakeholders about firm performance. Also, boards of directors and stakeholders signal their performance quality through an increase in the level of financial risk disclosures, and thus, a decrease in the level of information asymmetry (Elamer et al., 2019; Ntim et al., 2013). Therefore and given the inherent interdependencies or overlaps amongst the theories, this study argues that applying a framework that combines these theories will provide a richer basis for understanding and explaining the various motivations and variation of FRD within the UK context.

\subsection{Agency theory}

Corporate governance refers to the policies, processes, policies, customs and regulations which help in directing, controlling and administering a corporation (Baker \& Anderson, 2010). Corporate governance codes tend to specify the rights and responsibilities of the different stakeholders in a company. It articulates the relationship between the corporate governance and the immediate stakeholders, who are basically the employers and the shareholders (Baker \& Anderson, 2010).

From the corporate governance perspective, the agency theory is supposed to help the company executives or the corporate board leadership structure to better understand the interests of the shareholders, hence, working in a manner that seeks to safeguard their interests (Filatotchev \& Wright, 2010). FRD can be one way of safeguarding the interests of the 
shareholders by the company executives. According to the agency theory, a large board can be good in monitoring the performance of the firm. Thus, a firm with a large board is more likely to disclose more and more information, thereby leading to voluntary disclosure (Allini et al., 2015). In addition, the agency theory proposes that firms can improve their managerial monitoring as well as board independence by having a board that is diverse in terms of gender and ethnicity (Cabedo \& Tirado, 2004; Elzahar \& Hussainey, 2012; Ntim et al., 2013).

Moreover, corporate governance is seen as articulating the relationship that exists between the company and society; therefore, the concept of corporate governance is regarded as a core area of economic sociology. This is because the sociological study of corporate governance is largely concerned with the relationships that exist within the company but not just between the agents and the principals. It also focuses on the relationship between all of the stakeholders as well as in the mediation processes with the objective of attaining an effective organisation (Bainbridge, 2012). It is manageable to both improve the performance and decrease agency problems by using the lower levels of information asymmetry in such a manner where there is a concentrated ownership and increasing managerial monitoring (Greco, 2012; Jensen \& Meckling, 1976; Ntim et al., 2013).

\subsection{Stakeholder theory}

This theory is related to organisational management as well as business ethics, which look at addressing the values and morals involved in managing the affairs of corporate governance (Norwani et al., 2011). Unlike the agency theory, the stakeholder theory places emphasis on the fact that external stakeholders that are deemed to be affected by the affairs of the company have a right to be consulted on specific issues. From a corporate governance perspective, the stakeholder theory of the management of a company should view the general public, suppliers and surrounding community as indirect beneficiaries or victims of their actions or decisions. The 2007/2008 global financial crisis demonstrated the failure to adhere to the stakeholder theory by corporate executives. In relation to risk disclosure, the importance of FRD or any other form of financial disclosure is supposed to link a firm's management such as the CEO and the board of directors to shareholders as well as stakeholders (Ntim et al., 2013).

Financial disclosure is often viewed as a bridge designed to communicate or connect a firm with what can be termed as the external parties (stakeholders). How effective such a communication is can be used as a measurement in determining the outcome or performance of the firm. It is essential to point to the fact that shareholders of a firm need to be considered as an important stakeholder group in a similar manner to the suppliers, the customers, members of the local community and employees (Phillips, 2011). Therefore, a business organisation 
owes special duties to its investors as well as different responsibilities and obligations to various groups of stakeholders.

One of the key challenges of the stakeholder theory revolves around what can be termed as the unified concept of stakeholders. According to Filatotchev \& Wright (2010), one of the main questions asked is whom should the firm perform? In essence, the firm is placed in a very tight dilemma with regard to whose interests it can meet in order to be regarded as performing the legal obligations under corporate governance. This is because most of the stakeholder theorists have underestimated the influence of the shareholders in terms of advancing their interest. There is a need for stakeholder theorists to understand that when the needs of the shareholders are sufficiently met, it is much easier to advance the interests of the other stakeholder groups (Phillips, 2011; Mansell, 2013). The Enron scandal offers a good example of how the stakeholder theory can be undermined when the interests of the shareholders are not met by the management of the firm (Phillips, 2011). The board of directors of Enron conspired against the interest of the shareholders, thereby losing their confidence and leading to the eventual collapse of the company. Corporate risk disclosure plays a crucial role in advancing the stakeholder theory as it offers vital information to existing investors or shareholders as well as potential future investors who can be found in the other stakeholder groups.

\section{Literature review and hypothesis development}

\subsection{Board gender diversity and FRD}

From the perspective of a corporate board, there are various features present among the different board members or directors, which can affect their decision-making especially with regard to FRD policies and practices (Shultz \& Amacom, 2001; Dhir, 2015). These features range from the ones that can be directly observed such as ethnicity, age and gender as well as those features that are considered to be less visible, i.e., religion, education and occupation. A diverse board means that there is also mixed views on satisfactorily handling issues related to the interest of the firm (Mishra \& Jhunjhunwala, 2013). Western nations such as the UK can be credited with making significant strides when it comes to the inclusion of women in senior management and leadership positions such as the board of directors, which is contrary to the case in less developed countries (Dhir, 2015). Inclusivity is a valuable component of corporate governance because it provides a wider platform for participation and opinion sharing.

Disclosure is largely viewed as a managerial duty but the presence of diverse opinion is expected to put sufficient pressure on the management to engage in more disclosure (Mishra $\&$ Jhunjhunwala, 2013). The general characteristic among company directors that may have a 
significant influence on the company's decisions constitutes board diversity (Ntim et al., 2013; Van der Walt \& Ingley, 2003). It is possible to obtain resources as well as connect a company to the outside environment when the ethnic and gender backgrounds of their boards are diverse (Pfeffer \& Salancik, 1978; Oliveira et al., 2011; Ntim et al., 2013). Moreover, the agency theory proposes that firms can improve their managerial monitoring and board independence by having a board that is diverse in terms of gender and ethnicity (Cabedo \& Tirado, 2004; Elzahar \& Hussainey, 2012; Ntim et al., 2013).

Barako and Brown (2008) and Ntim et al. (2012a) also suggest that voluntary disclosures are positively influenced by board diversity; while Ntim and Soobaroyen (2012) observe that less diverse boards experience less CSR reporting compared to companies that have more diverse boards. Ntim et al. (2013, p.377) observe that "corporate boards that are made up of diverse ethnic and gender backgrounds tend to increase the probability of there being more voluntary disclosures". This can indicate that female members disclose more information than male members on the board of directors in UK firms. This leads us to the third hypothesis will be as follows:

$H_{1}$ - there is a significant positive relationship between the female gender of a corporate board and the efficiency of corporate FRD.

\subsection{Block ownership and FRD}

Agency theory suggests that improved FRD may reduce agency problems through lower levels of information asymmetry, as well as increased managerial monitoring (Ntim et al., 2013; Greco, 2012; Jensen \& Meckling, 1976). Previous research (Ntim et al., 2013; Beretta \& Bozzolan, 2004; Oliveira et al., 2011) shows that dispersed ownership structures lead to more voluntary disclosure when compared to concentrated ownership. For instance, Ntim et al. (2014) show that block ownership is negatively associated with the level of FRD. However, Allini et al. (2015) argued that there is a positive association between block ownership and FRD. Therefore, this can imply that UK firms will engage in a high level of FRD, including voluntary disclosures (Oliveira et al., 2011; Abraham \& Cox, 2007). Therefore, we hypothesise that

$\mathrm{H}_{2}$ : there is a negative relationship between block ownership and corporate FRDs.

\subsection{Board size and FRD}

Agency theorists suggest that larger boards are positively influencing performance, FRD and corporate disclosures by enhancing managerial monitoring (Bozec \& Bozec, 2012; Elzahar \& Hussainey, 2012; Ntim et al., 2013). Similarly, the stakeholder theory argues that a larger board can ensure the security of critical business resources, such as finances and contracts and 
minimise uncertainty due to the accessibility to the external environment of the firms, which is enhanced by a larger board (Jia et al., 2009, cited in Ntim et al., 2013). Furthermore, stakeholder theory argues that expertise through diversity is also brought by larger boards (Branco \& Rodrigues, 2006; Linsley et al., 2006; Ntim et al., 2013), as well as diversity in terms of representation from other stakeholder (Freeman, 1984, cited in Ntim et al., 2013) which improves reputation (Suchman, 1995; Raj \& Handley-Schachler, 2009).

However, other theorists suggest that smaller boards are the most appropriate because they enhance disclosure and performance and are at the same time more effective (Jensen \& Meckling, 1976; Ntim et al., 2013). Larger boards come with more director free-riding, poor monitoring, communication and coordination, which affects performance and FRD negatively. Also, it can be argued that smaller boards enhance disclosure and performance because they enable frequent discussions that are more effective and candid. According to Ntim et al. (2013), board size is positively related to the extent of FRD. However, Elzahar and Hussainey (2012) suggest that there is no relationship between board size and FRD. This leads to the fourth hypothesis, which states that:

H3: there is no significant relationship between board size and corporate FRDs.

\section{Research design}

\subsection{Data and sample consideration}

This study examines UK companies' annual reports in terms of the association between corporate governance characteristics, ownership structure and the extent of FRD. An FRD index is developed to measure the level of disclosure1.

The sample was 50 non-financial UK firms listed on the London Stock Exchange between 2011 and 2015. The selection of the study sampled was ten different types of industry sectors, which are food producers, food and drug retailers, oil and gas producers, personal goods, leisure goods, tobacco, gas and water, electricity, mobile telecommunication and beverages. We began in 2011 to ensure that data influenced by or related to the global financial crisis of 2007/2009 was excluded.

\subsection{Variables and measures}

Financial Risk Disclosure (FRD) - The study employs the content analysis in measuring the FRD, which is the dependent variable. The content analysis method will be suitable for

\footnotetext{
${ }^{1}$ For the individual items contained in the index, see the appendix.
} 
measuring this dependent variable because it looks at the amount of extent as opposed to the level and quality of FRD (Adhikariparajul et al., 2019; Alnabsha et al., 2018; Alshbili et al., 2019; Elamer, 2017; Elamer et al., 2018; Elamer \& Benyazid, 2018; Elamer et al., 2019; Elamer et al., 2017; Elmagrhi et al., 2019). We employed the FRD index developed by Ntim et al. (2013) and Elamer et al. (2019). Table 1 shows the variables that will be used in the study.

Table 1: List of Variables and their Measurements

\begin{tabular}{|c|c|c|}
\hline Variable & Acronym & Proxy(coding) \\
\hline \multicolumn{3}{|l|}{ Dependent variable } \\
\hline $\begin{array}{l}\text { Corporate financial risk } \\
\text { disclosure }\end{array}$ & FRD & $\begin{array}{l}\text { This will be measured as risks that arise from } \\
\text { major changes such as a shift in the interest } \\
\text { rates; exchange rates; equity prices; commodity } \\
\text { prices; liquidity; credit; financial } \\
\text { instruments/derivatives; capital } \\
\text { adequacy/insolvency; and executive } \\
\text { compensation. }\end{array}$ \\
\hline \multicolumn{3}{|l|}{ Independent variable } \\
\hline Block ownership & BOWN & $\begin{array}{l}\text { Percentage of ordinary shares that are held by the } \\
\text { shareholders who have at least } 3 \% \text { of the total } \\
\text { ordinary shareholdings of the company }\end{array}$ \\
\hline Board gender & BG & $\begin{array}{l}\text { Percentage of female directors to the total number } \\
\text { of directors on the firm's board }\end{array}$ \\
\hline Board size & BSIZE & $\begin{array}{l}\text { Measured as the natural log of all the total } \\
\text { number of company directors that are on the } \\
\text { board of a given company }\end{array}$ \\
\hline \multicolumn{3}{|l|}{ Control variables } \\
\hline $\begin{array}{l}\text { A firm that has an } \\
\text { established corporate } \\
\text { governance committee }\end{array}$ & CGCO & $\begin{array}{l}\text { Measured as either } 1 \text {, that is where a company } \\
\text { has established a corporate governance } \\
\text { committee or } 0 \text {, otherwise. }\end{array}$ \\
\hline $\begin{array}{l}\text { A firm that has a corporate } \\
\text { social responsibility } \\
\text { committee }\end{array}$ & CSRCO & $\begin{array}{l}\text { Measured as either } 1 \text {, which is where a company } \\
\text { has established a corporate social responsibility } \\
\text { committee or } 0 \text {, otherwise. }\end{array}$ \\
\hline $\begin{array}{l}\text { A firm that is listed on a } \\
\text { foreign stock market }\end{array}$ & CLIST & $\begin{array}{l}\text { Measured as either } 1 \text {, which is where a company } \\
\text { is listed on a foreign stock market or } 0 \text {, otherwise. }\end{array}$ \\
\hline
\end{tabular}

\subsection{Model Specification}

The study adopts a multiple regression to investigate the relationship between corporate governance and FRD as follows.

$$
\mathrm{FRD}=\beta 0+\beta 1 * \mathrm{BOWN}+\beta 2 * \mathrm{BG}+\beta 3 * \mathrm{BSIZE}+\beta 4 * \mathrm{CGCO}+\beta 5^{*} \mathrm{CSRCO}+\beta 6^{*} \mathrm{CLIST}
$$


Where,

FRD is the corporate financial risk disclosure, BOWN is the block ownership, BG is the board gender, BSIZE is the board size, CGCO is a firm that has an established corporate governance committee, CSRCO is a firm that has an established corporate social responsibility committee, CLIST is a listed firm on a foreign stock market, $\beta 0$ is regarded as a constant coefficient of this regression model, The parameters $\beta 1$ to $\beta 7$ are unknown parameters for the independent and control variable, $\varepsilon$ is the standard error of the regression model. Consequently, our conceptual framework is depicted in Fig 1. 


\section{Empirical analysis and discussion}

\subsection{Descriptive statistics and correlation analysis}

Table 2 shows the descriptive statistics for all of the variables of this study; independent, dependent and control variables.

Table 2: Descriptive Statistics

\begin{tabular}{|c|c|c|c|c|c|c|}
\hline Variables & Observation & Minimum & Maximum & Mean & Medium & STD \\
\hline \multicolumn{7}{|l|}{ Dependent Variable } \\
\hline FRD $(\%)$ & 250 & 30 & 100 & 65.20 & 70.00 & 16.03 \\
\hline \multicolumn{7}{|c|}{ Independent Variables } \\
\hline BOWN $(\%)$ & 250 & 3.00 & 91.10 & 39.66 & 39.03 & 21.66 \\
\hline Board Gender (\%) & 250 & 0.00 & 50.00 & 16.32 & 17.00 & 10.60 \\
\hline BSIZE & 250 & 3.00 & 16.00 & 9.252 & 9.00 & 2.77 \\
\hline \multicolumn{7}{|l|}{ Control Variables } \\
\hline $\mathrm{CGCO}$ & 250 & 0.00 & 1.00 & 0.74 & 1.00 & 0.43 \\
\hline CSRCO & 250 & 0.00 & 1.00 & 0.30 & 0.00 & 0.45 \\
\hline CLIST & 250 & 0.00 & 1.00 & 0.28 & 0.00 & 0.44 \\
\hline
\end{tabular}

The FRD variable has an average ratio of $65.2 \%$. The FRD ranges from a minimum of $30 \%$ to a maximum of $100 \%$, with the median firms disclosing $65.20 \%$ and the medium is $70 \%$, which is seven items divided by ten $7 / 10$ sentences (disclosure index score) with a standard deviation of $16.03 \%$ of the FRD. The result is consistent with the findings of Elshandidy et al. (2015) and Ntim et al. (2013).

Block Ownership (BOWN) - block ownership has an average of 39.66\%, which ranges from a minimum of $3 \%$ to a maximum of $91.1 \%$ with a standard deviation of $21.665 \%$. The block ownership statistic is much higher than the last 10 years in terms of mean value, which is $39.66 \%$. This is in contrast to the fact that the UK is largely characterised by dispersed ownership (Ruiz-Mallorqui \& Santana-Martin, 2011). This result is supported by the findings of Oliveira et al. (2011) and Abraham and Cox (2007).

Board Gender Diversity Variable (BG) - the maximum percentage of females on the corporate board is only $50 \%$ with the average number being $16.3 \%$. This statistical outcome shows that the participation of women on corporate boards within the UK during the period covered by this study can be said to be still low. This finding appears to be close to the findings made by the previous studies (Ntim et al., 2012a; Barako \& Brown, 2008; Ntim et al., 2013). Hence, the descriptive statistics have shown that the participation of women on the corporate board of directors has an average of $16.32 \%$, which is the average of the participation of women 
on the corporate board for the 10 different types of industry sector. It ranges from a minimum of $0 \%$ to a maximum of $50 \%$ with the median firms disclosing $16.30 \%$ of the total number of the board for the UK-based firms sentences with a standard deviation of $10.60 \%$. This means that the participation of women on the corporate boards is still lower than the participation of men.

The size of the corporate board in terms of the number of directors ranges from three to 16 people with the usual number being nine and a standard deviation of $2.7733 \%$. The UK Corporate Governance Code has not clearly specified the number of corporate board directors that a company should have in place but only states that a corporation should maintain a proper size of the board. The findings of this study appear to be supporting the research findings made by Allini et al. (2015), Elzahar \& Hussainey (2012) and Jensen (1993) that an effective corporate board should have a number of directors that does not exceed seven or eight; otherwise, the proper functioning of the board might decline if the number is too large. However, varying opinions have emerged regarding the number of corporate board members such as the proposal made by Lipton \& Lorsch (1992) and Elzahar \& Hussainey (2012) who indicate that the ideal number of corporate board members should be between eight and nine. The average number of corporate board members in the case of this study is lower than the mean board size in the UK as mentioned by Vafeas \& Theodorou (1998), which is 8.07.

Table 3 indicates the correlation matrix, which is under the Pearson correlation assuming that the model for this study has been normally distributed.

The correlation matrix can be used as a tool when it comes to checking for the multicollinearity problem within the regression model. Table 3 does not contain any coefficient that appears to exceed the 0.8 limit point, which is an indication that there is usually no existing multicollinearity problem within this particular model. 
Table 3: Correlation Matrix

\begin{tabular}{|l|l|l|l|l|l|l|l|}
\hline & FRD & BOWN & Board Gender & BSIZE & CGCO & CSRCO & CLIST \\
\hline FRD & 1 & & & & & & \\
\hline BOWN & $0.148^{*}$ & 1 & & & & & \\
\hline Board Gender & $0.143^{*}$ & $-0.364^{* *}$ & 1 & & & & \\
\hline BSIZE & 0.000 & $-0.517^{* *}$ & $0.275^{* *}$ & 1 & & & \\
\hline CGCO & -0.070 & $-0.169^{* *}$ & 0.039 & $0.176^{* *}$ & 1 & & \\
\hline CSRCO & $-0.235^{* *}$ & $-0.255^{* *}$ & $0.183^{* *}$ & $0.167^{* *}$ & 0.090 & 1 & \\
\hline CLIST & 0.048 & $-.283^{* *}$ & $0.168^{* *}$ & $0.384^{* *}$ & $0.370^{* *}$ & -0.019 & 1 \\
\hline
\end{tabular}

Notes: * Correlation is significant at the 0.05 level (2-tailed).

** Correlation is significant at the 0.01 level (2-tailed).

Table 3 shows that there is a significant positive relation between BOWN and FRD at a $5 \%$ level, with a correlation coefficient of 0.148 . This indicates that block ownership has an effect on FRD. Therefore, public interest and accountability in such firms are relatively unlimited. In addition, these firms will engage in a high level of FRD, including voluntary disclosures. This finding confirmed previous results from Oliveira et al. (2011) and Abraham \& Cox (2007) that there is a positive association with FRD in particular and voluntary disclosure in general (Allini et al., 2015). However, the BSIZE, CGCO and CLIST have not correlated with FRD. These findings confirmed by Elzahar \& Hussainey (2012).

\subsection{Multivariate regression Results}

The multiple regression model (Table 4) for all the predictors (BOWN, board gender, BSIZE, CGCO, CSRCO, and CLIST) produced R2 $=0.130$, adjusted R2 = 0.109, F-value= 6.052, significant at a $1 \%$ level $(\mathrm{P}<0.000)$. The adjusted $\mathrm{R}$ square demonstrates the percentage which is the change in the dependent variable, which can be explained by the set of the independent and control variables in the model. This implies that the independent variables predict $10.9 \%$ of the FRD in the UK listed firms on the London Stock Exchange over the five years of investigation.

This can imply that the influence of corporate governance on FRD is $10.9 \%$ only over the five years. This can confirm previous studies, for example, the result is rather consistent with the findings of Ntim et al. (2013) who suggested that "the corporate risk discloser is largely non-financial (i.e., mainly 'operational' and 'strategic' risks)' 'historical', 'good news' and 
'qualitative' in nature over the ten-year period investigated". But they have three different categories, however, this study has only one category of corporate risk discloser which is FRD, representing one-third of CRD categories in their study. According to the coefficient in Table 4, the regression equations for the average of the five years from 2011 to 2015 are given as follows:

$\mathrm{FRD}=8.955+2.993 \mathrm{BOWN}+3.750 \mathrm{BG}+1.055 \mathrm{BSIZE}-0.761 \mathrm{CGCO}-3.707 \mathrm{CSRCO}+$ 0.713 CLIST $+\varepsilon$

Table 4: Regression analysis results

\begin{tabular}{|c|c|c|c|c|c|}
\hline \multirow[t]{2}{*}{ Model } & \multicolumn{2}{|c|}{$\begin{array}{l}\text { Unstandardised } \\
\text { Coefficients }\end{array}$} & $\begin{array}{l}\text { Standardised } \\
\text { Coefficients }\end{array}$ & \multirow[t]{2}{*}{$\mathrm{t}$} & \multirow[t]{2}{*}{ P-value } \\
\hline & B & Std. Error & Beta & & \\
\hline (Constant) & 51.847 & 5.790 & & 8.955 & 0.000 \\
\hline BOWN & 0.164 & 0.055 & 0.222 & 2.993 & 0.003 \\
\hline Board Gender & 0.371 & 0.099 & 0.245 & 3.750 & 0.000 \\
\hline BSIZE & 0.448 & .425 & 0.078 & 1.055 & 0.293 \\
\hline CGCO & -1.807 & 2.375 & -0.050 & -0.761 & 0.447 \\
\hline CSRCO & -8.171 & 2.204 & -0.234 & -3.707 & 0.000 \\
\hline CLIST & 1.780 & 2.496 & 0.050 & 0.713 & 0.476 \\
\hline \multicolumn{6}{|c|}{ Further analytical results (diagnostic criteria) } \\
\hline \multicolumn{3}{|l|}{ R Square } & \multicolumn{3}{|l|}{0.130} \\
\hline \multicolumn{3}{|c|}{ Adjusted R Square } & \multicolumn{3}{|l|}{0.109} \\
\hline \multicolumn{3}{|l|}{ F-ratio } & \multicolumn{3}{|l|}{6.052} \\
\hline \multicolumn{3}{|l|}{ Durbin-Watson } & \multicolumn{3}{|l|}{0.498} \\
\hline \multicolumn{3}{|l|}{ Significant } & \multicolumn{3}{|l|}{0.000} \\
\hline \multicolumn{3}{|c|}{ Std. error of the estimate } & \multicolumn{3}{|l|}{15.1415} \\
\hline
\end{tabular}

\subsection{Discussion}

From Table 4, the regression reveals a positive significant result at a $1 \%$ level for BOWN (+) and board gender (+), but a negative significant result at a $1 \%$ level for CSRCO (-). However, the regression has shown that there is no statistical relationship between those variables BSIZE (+), CGCO (-), CLIST (+) and the FRD. These results are consistent with four of the formulated hypotheses: H1 (BOWN), H3 (board gender), H4 (BSIZE) and H5 (CSRCO). Those hypotheses were accepted, but H2 (DBLS) was rejected due to the constancy of this variable.

\subsubsection{Block Ownership Variable (BOWN)}

Block ownership of the non-financial UK listed firms is significantly positively related to FRD at a $99 \%$ level of confidence in the regression and is consistent with the prior correlation analysis. Nevertheless the $\mathrm{P}$ value of the block ownership is 0.003: this value is significant at a 0.01 level which is highly related to the FRD and its attributes. The P value was less than 5\% 
which means that there is a significant positive relationship between block ownership and FRD. Furthermore, this result is substantially consistent with the prior correlation analysis, where the correlation coefficient value was 0.148 . That can imply that the power which is owned by the block ownership in the UK firms that is $3 \%$ or more than $3 \%$ (which is required by the firms' rules) in the status positions of the right to vote or decision makers, can lead to a better level of FRD. This is due to their interest and also to maximise the volume for the shareholder as well as the stakeholder. Furthermore, it minimises the agency problem as well as the financial risk in the business. This result converses the multi-theoretical framework, which incorporates insights from agency, stakeholder, shareholder. This indicates that block ownership has an effect on FRD. Furthermore, public interest and accountability in such firms are relatively unlimited. Therefore, this can imply that the UK firms will engage in a high level of FRD, including voluntary disclosures. This result supports the findings of Oliveira et al. (2011) and Abraham \& Cox (2007). There is a positive association with FRD in particular and voluntary disclosure in general (Allini et al., 2015). In this study the regression result has shown that block ownership is positively related to the level of FRD. However, the result is inconsistent with the findings of Allini et al. (2015) and Ntim et al. (2013). Block ownership is negatively associated with the level of FRD which is one category of CRD. Therefore, the contrasting results between Ntim et al. (2013) and this paper may result from the different corporate governance codes and backgrounds of South Africa and the UK.

\subsubsection{Board Gender}

Board gender of the non-financial UK listed firms is significantly positively related to FRD at a $99 \%$ level of confidence in the regressions and is consistent with the prior correlation analysis. Moreover, the $\mathrm{P}$ value of the board gender is 0.000 and this value is significant at a 0.01 level which is highly related to FRD and its attributes. The $\mathrm{P}$ value was less than $5 \%$ which means that there is a significant positive relationship between board gender and FRD. Furthermore, this result is substantially consistent with the prior correlation analysis, where the correlation coefficient value was 0.166 . This can indicate that female members disclose more information than male members on the board of directors in the UK firms. This result supports the findings of Ntim et al. (2012a), Barako \& Brown (2008) and Ntim et al. (2013), who argued that "corporate boards of diverse ethnic and gender backgrounds tend to make more voluntary disclosures" (Ntim et al., 2013, p.377). Furthermore, the evidence added to the results of the previous studies (Mahadeo et al., 2012; Carter et al., 2003) indicate that board gender and ethnicity has a positive impact on company outcomes. 
This result converses the multi-theoretical framework which incorporates insights from agency, shareholder, stakeholder. This can lead relatively to the formation of board diversity. This might cause more pressure (especially by the female members and black ownership) to engage in greater FRD which is one category of CRD (ibid.). Even the percentage of females on the corporate board is still low with a maximum of $50 \%$ only and an average number of $16.3 \%$, confirmed by Table 3 (Descriptive Statistics). The result is strongly consistent with the findings of Ntim et al. (2013), who found that board diversity is positively related to the extent of FRD in nature over the five-year period investigated. Furthermore, Adams and Ferreira (2009) supported this point of view by indicating that the difference in gender can offer new experiences and knowledge. However, this may lead to board conflict problems. Thus, board gender can lead to an improvement in board effectiveness, and have a good impact on firms' FRD as well.

In addition, female directors have simply received attention in the economic downturn period. For instance, the CG code in China does not require board gender diversity (Deloitte, 2015), but the UK Corporate Governance Regulation requires the presence of females on the board, ordered by the Higgs report in 2003 to improve the efficacy of board directors.

\subsubsection{Board Size (BSIZE)}

According to the coefficient in Table 4 the board size of the non-financial UK listed firms has not influenced FRD, with a $\mathrm{P}$ value of 0.293 in nature over the five-year investigating period. This is more than $5 \%$ which means that there is no relationship between board size and FRD. The regression result has shown that there is no relationship between the board size and FRD. This result also supports the findings of Elzahar \& Hussainey (2012) who suggest that there is no relationship between board size and FRD. Furthermore, this result is substantially consistent with the prior correlation analysis, where the correlation coefficient value was -0.47 which is an insignificant relationship. Otherwise, the result is inconsistent with the findings of Ntim et al. (2013), who found that board size is positively related to the extent of FRD. It is possible to positively influence performance, FRD and corporate disclosures with larger boards and enhanced managerial monitoring as suggested by the agency theory (ibid.). Similarly, the stakeholder theory states that larger boards ensure the security of critical business resources such as contracts and finance and minimise uncertainty because accessibility to a company's external environment is enhanced by a larger board (Jia et al., 2009, cited in Ntim et al., 2013).

This finding is supported by the multi-theoretical framework which incorporates insights from agency, stakeholder, shareholder. This finding can imply that board size has no influence on the requirements of FRD in the UK listed firms on the London Stock Exchange over the 
five-year period of investigation. The finding can be explained by the nature of the financial risk over this period. Therefore, the contrasting result between Ntim et al. (2013) and this paper may result from the different corporate governance codes and background of South Africa and the UK.

\subsubsection{Corporate Social Responsibility Committee (CSRCO)}

According to Table 4, there is a very significant negative relationship between CSRCO and FRD at a $1 \%$ level, with a P-value of -0.000 in nature over the five-year investigation period, which is less than $5 \%$. This means that there is no relationship between board size and FRD. This can indicate that firms that have established a corporate social responsibility committee will disclose less than firms without an established CSRCO. It has a negative impact on FRD, in terms of encouraging CSR in the UK. Moreover, this result is substantially consistent with the prior correlation analysis, where the correlation coefficient value was 0.232. The CSRCO of the non-financial UK listed firms negatively influences FRD. This result is in line with the findings obtained by Ntim et al. (2013), Khan et al. (2013) and Reverte (2009) who observed that closely-held companies can disclose substantially less information in terms of CSR practices (ibid.). According to Ntim et al. (2013), CSR and voluntary disclosure can reduce the incidences of corruption and fraud. Furthermore, they have linked CSR with the diversity of the board and board size. The CSR reporting will be high if the board is more diverse and if the larger boards disclose more information in terms of CSR practices and voluntary disclosure.

\subsubsection{CGCO and CLIST}

The CGCO and CLIST have no significant connection with the level of FRD. They were control variables, with a P-value of -0.761 and 0.713 , respectively. This is substantially more than $5 \%$, which means that there is no relationship between those two variables and FRD. Nevertheless, taking into consideration the prior correlation analysis the results were substantially consistent, with the correlation coefficient values at -0.067 and 0.063 respectively. This can imply that there is no relationship between the corporate governance committee and cross-listing on influencing the level of FRD. This finding is supported by Elzahar \& Hussainey (2012) who observed that cross-listing UK firms have no influence on FRD. Taylor et al. (2010) argued that cross-listing is negatively connected with FRD patterns. This result is inconsistent with prior research that found a positive association between overseas stock exchange listing firms and FRD (Rajab \& Handley-Schachler, 2009; Mangena \& Pike, 2005). Cross-listing can give firms an opportunity to access many alternate finance sources. Even if there is an additional risk disclosure required by different regulatory frameworks, the board of directors 
has an incentive to provide more financial risk information in its financial reports. Thus, the securities will be more attractive, helping directors to send good signals about risk management activities, operations' sustainability and different risks including FRD. Previous risk disclosure studies have shown a positive relationship between cross-listing firms and the levels of risk disclosure (ibid.).

According to IAS 34, the requirement of disclosure in UK annual reports is greater than the interim report disclosure. Thus, UK listed firms are required to disclose more information in the annual reports than the interim reports, which can lead to voluntarily disclosure. Furthermore, the half-yearly reporting in the UK is one of the requirements of the London Stock Exchange (Elzahar \& Hussainey, 2012).

With respect to the determinants of FRD, this study finds that BOWN and board gender are significantly positively related to the level of FRD, whereas CSRCO is significantly negatively associated with the level of FRD. By contrast, board size has no significant connection with the level of FRD.

Table 5: Summary of Hypotheses Tested

\begin{tabular}{|l|l|l|}
\hline No & Hypotheses & Results \\
\hline H1 & $\begin{array}{l}\text { There is a significant positive relationship between a block ownership structure of } \\
\text { corporate organisation and the efficiency of FRD. }\end{array}$ & Accepted \\
\hline $\mathbf{H 2}$ & $\begin{array}{l}\text { There is a significant positive relationship between the female gender of a corporate } \\
\text { board and the efficiency of FRD. }\end{array}$ & Accepted \\
\hline $\mathbf{H 3}$ & $\begin{array}{l}\text { There is no significant relationship between the board size and the FRD. } \\
\text { H4 }\end{array}$ & $\begin{array}{l}\text { There is a significant negative relationship between the corporate social } \\
\text { responsibility committee and the level of FRD. }\end{array}$ \\
\hline
\end{tabular}

\section{Summary and conclusion}

The focus of this study was to investigate the relevant impacts of corporate governance in terms of financial risk reporting in the UK. In particular, the study sought to investigate and analyse how corporate governance mechanisms influence the system of financial risk reporting among UK firms. The following are the sub-objectives that guided the undertaking of this study: (i) to investigate and analyse the level of FRD by UK firms and (ii) to investigate and analyse the determinants of risk disclosure by UK firms. The study used a quantitative research design and applied a descriptive research design. The target population for the study included 
all UK firms that are listed on the London Stock Exchange and were operational between 2011 and 2015. The sample population was $50 \mathrm{UK}$ non-financial listed firms operating in 10 different types of industry sectors, which are food producers, food and drug retailers, oil and gas producers, personal goods, leisure goods, tobacco, gas and water, electricity, mobile telecommunication and beverages. The timespan was from 2011 to 2015 for those companies who witnessed a change in FRD during this period of time. Multiple regression analysis was used to test the relationship between corporate governance mechanisms and FRD by UK firms.

The findings of this study point to the conclusion that corporate governance has a significant influence on FRD especially in the case of the levels of risk disclosure in the annual reports. With respect to the determinants of FRD, this study finds that there are positive correlations between block ownership, board gender and FRD, which are significantly related to the level of FRD. In this study, the regression result has shown that block ownership is positively related to the level of FRD. Block ownership is negatively associated with the level of FRD, which is one category of CRD. A positive relationship is observed between board gender and FRD, with this result supporting the findings of Ntim et al. (2012a), Barako \& Brown (2008) and Ntim et al. (2013), who argued that "corporate boards of diverse ethnic and gender backgrounds tend to make more voluntary disclosures" (Ntim et al., 2013, p.377). Furthermore, the evidence added to the results of previous studies (Mahadeo et al., 2012; Carter et al., 2003) that indicate that board gender and ethnicity have a positive impact on company outcomes.

The CSR committee is negatively associated with the level of FRD. The negative result has been confirmed by Ntim et al. (2013), Khan et al. (2013) and Reverte (2009) who observed that closely-held companies disclose substantially less information on their CSR practices, which will lead to a negative influence on FRD. In addition, this contrasts with the requirements of IAS 34. By contrast, the board size, CGCO, CLIST and DBLS have no significant connection with the level of FRD. The regression result has shown that there is no relationship between the board size, CLIST and FRD. This result supports the findings of Elzahar \& Hussainey (2012) who suggest that there is no relationship between board size, CLIST and FRD. Furthermore, this result is substantially consistent with the previous correlation analysis. However, according to Taylor et al. (2010) cross-listing is negatively connected with FRD patterns.

This finding has provided empirical support for the predictions of a multi-theoretical framework. It is also consistent with the findings of Ntim et al. (2013), Elzahar \& Hussainey (2012), Khan et al. (2013), Barako and Brown (2008) and Allini et al. (2015). Nevertheless, 
with consideration of the previous correlation analysis, the results were substantially consistent. The testing of the hypotheses (H1 to H4) provided results that accepted the hypotheses as correct as summarised below in accordance to the variables used in the study.

The findings of this study are expected to contribute to the literature on corporate governance and FRD and in particular in the context of publicly listed firms in the UK. Due to the nature of the London Stock Exchange, which makes it more complex to undertake a broadbased study, the findings of this study provide correct evidence on how corporate governance mechanisms affect FRD among UK publicly listed firms. This is because the study used a multi-theoretical framework, where the study looks into essential and relevant theories such as agency and stakeholder. The findings of this study will enhance understanding with regard to the level of FRD and the determinants of risk disclosure, such as the corporate ownership structure and the characteristics of a corporate board. In addition, the findings of this study are expected to add to the literature regarding the relationship between corporate governance features and practices of FRD in developed countries such as the UK. This study has significant implications for policy-makers, investors and regulators. Evidence of growing FRD implies that efforts by several stakeholders have had some positive impact on the level of FRD in the firms examined. Though, given the varied variances in the level and focus of FRD indicates that some attention to the quality of information released by firms is essential if they are to be valuable to stakeholders, such as investors. Second, the results show the importance of current $\mathrm{CG}$ reforms in the UK and their impact on enhancing FRD. Examples of such changes include increasing board size and gender diversity acting as effective firm-level advisors and monitors of FRD. As a consequence, regulators and policymakers should continually pursue reforms to encourage firms to follow CG principles that are promoted as good practice.

The London Stock Exchange is ranked among the largest and most advanced stock exchanges in the world. As a result, it has a huge and growing number of listed firms. This was one of the main limitations experienced during the undertaking of this study; hence, the focus was only on a small sample population of 50 non-financial firms. This was a drop in the ocean compared to the 2,324 firms that are listed on the London Stock Exchange. Another major limitation was that the firms listed are mixed in terms of their nature and size of operations, thereby presenting a challenge when it came to the generalisation of the findings of this study. The nature of this study introduces time limitations as the researcher was expected to spend 15 days collecting the secondary data. However, it took 35 days due to the complexity in the annual reports of the firms. Although some of the data were available online, there were certain 
cases of data that needed to be manually accessed, making it expensive and cumbersome for the researcher.

Given the limitations discussed above, this study suggests some recommendations to encourage the undertaking of further research relating to corporate governance and FRD. This study mainly focused on the impact of corporate governance when it comes to FRD in firms' annual reports that are listed on the London Stock Exchange. Since the focus of this study was confined within the UK corporate context, further research studies can seek to expand the focus or context by looking at developing as well as emerging economies such as China, India, South Africa and Brazil. The period of observation for this study (2011 - 2015) appears to be quite short if the changes of corporate governance can be properly analysed in a fast-changing world. As a result, there is a need for a study that looks at the impact of corporate governance on FRD in the pre-global financial crisis period, during the crisis as well as after the crisis in order to examine if there is a pattern with regard to the changes experienced in the global economy. There is a need to focus on other variables different from the ones covered in this study, which aim to examine more deeply the impact of other variables, such as corporate board characteristics and ownership structure when it comes to the level of FRD by firms. 


\section{References}

Abor, J., \& Fiador, V. (2013). Does corporate governance explain dividend policy in SubSaharan Africa?. International Journal of Law and Management, 55(3), 201-225.

Abraham, S., \& Cox, P. (2007). Analysing the Determinants of Narrative Risk Information in UK FTSE 100 Annual Reports. The British Accounting Review, 39(3), 227-248.

Adams, R. B., \& Ferreira, D. (2009). Women in the boardroom and their impact on governance and performance. Journal of Financial Economics, 94(2), 291-309.

Adhikariparajul, M., Hassan, A., Fletcher, M., \& Elamer, A. A. (2019). Integrated reporting in UK higher education institutions. Sustainability Accounting, Management and Policy Journal, Forthcoming. doi:10.1108/SAMPJ-03-2018-0093

Allini, A., Manes Rossi, F., \& Hussainey, K. (2015). The Board's Role in Risk Disclosure: An Exploratory Study of Italian Listed State-Owned Enterprises. Public Money \& Management, 36(2), 113-120.

Alnabsha, A., Abdou, H. A., Ntim, C. G., \& Elamer, A. A. (2018). Corporate boards, ownership structures and corporate disclosures: Evidence from a developing country. Journal of Applied Accounting Research, 19(1), 20-41.

Alshbili, I., Elamer, A. A., \& Beddewela, E. (2019). Ownership types, corporate governance and corporate social responsibility disclosures: Empirical evidence from a developing country. Accounting Research Journal, Forthcoming. doi:10.1108/ARJ-03-20180060

Bainbridge, S. M. (2012). Corporate governance after the financial crisis.

Baker, H. K., \& Anderson, R. (2010). Corporate governance: A synthesis of theory, research, and practice. Hoboken, NJ: John Wiley \& Sons.

Barako, D. G., \& Brown, A. M. (2008). Corporate social reporting and board representation: Evidence from the Kenyan banking sector. Journal of Management and Governance, 12, 309-324

Beretta, S., \& Bozzolan, S. (2004). A Framework for the Analysis of Firm Risk Communication. The International Journal of Accounting, 39, 265-288.

Bozec, R., \& Bozec, Y. (2012). The use of governance indexes in the governanceperformance relationship literature: International evidence. Canadian Journal of Administrative Sciences, 29, 79-98.

Branco, M. C., \& Rodrigues, L. L. (2006). Corporate social responsibility and resource based perspectives. Journal of Business Ethics, 69, 111-132.

Branco, M. C., \& Rodrigues, L. L. (2008). Factors Influencing Social Responsibility Disclosure by Portuguese Companies. Journal of Business Ethics, 83, 685-701.

Cabedo, J. D., \& Tirado, J. M. (2004). The disclosure of risk in financial statements. Accounting Forum, 28, 181-200

Carter, D. A., Simkins, B. J., \& Simpson, W. G. (2003). Corporate Governance, Board Diversity, And Firm Value. Financial Review, 38, 33-53.

Cheffins, B. R. (2015). The Rise of Corporate Governance in the UK: When and Why. Current Legal Problems, 68(1), 387-429.

Dhir, A. (2015). Challenging boardroom homogeneity: Corporate law, governance, and diversity.

Elamer, A. A. (2017). Empirical essays on risk disclosures, multi-level governance, credit ratings, and bank value: evidence from MENA banks. (Doctoral Thesis), University of Huddersfield, Huddersfield, UK. Retrieved from http://eprints.hud.ac.uk/id/eprint/31700 
Elamer, A. A., AlHares, A., Ntim, C. G., \& Benyazid, I. (2018). The corporate governancerisk-taking nexus: evidence from insurance companies. International Journal of Ethics and Systems, 34(4), 493-509.

Elamer, A. A., \& Benyazid, I. (2018). The impact of risk committee on financial performance of UK financial institutions. International Journal of Accounting and Finance, 8(2), 161-180.

Elamer, A. A., Ntim, C. G., Abdou, H., Zalata, A., \& Elmagrhi, M. (2019). The impact of multi-layer governance on bank risk disclosure in emerging markets: The case of Middle East and North Africa. Accounting Forum, Forthcoming.

Elamer, A. A., Ntim, C. G., \& Abdou, H. A. (2017). Islamic governance, national governance, and bank risk management and disclosure in MENA countries. Business \& Society, Forthcoming. doi:10.1177/0007650317746108

Elmagrhi, M., Ntim, C. G., Elamer, A. A., \& Zhang, Q. (2019). A study of environmental policies and regulations, governance structures and environmental performance: The role of female directors. Business Strategy and the Environment, 28(1), 206-220.

Elshandidy, T., Fraser, I., \& Hussainey, K. (2015). What drives mandatory and voluntary risk reporting variations across Germany, UK and US? British Accounting Review,47(4), 376-394.

Elshandidy, T. D., \& Neri, L. (2014). Corporate Governance, Risk Disclosure Practices, and Market Liquidity: Comparative Evidence from the UK and Italy. Corporate Governance: An International Review, 23(4), 331-356.

Elzahar, H., \& Hussainey, K. (2012). Determinants of narrative risk disclosures in UK interim reports. Journal of Risk Finance, 13(2), 133-147.

Fatima, S., Mortimer, T., \& Bilal, M. (2018). Corporate governance failures and the role of institutional investors in Pakistan: lessons to be learnt from UK. International Journal of Law and Management, 60(2), 571-585.

Filatotchev, I., \& Wright, M. (2010). Agency Perspectives on Corporate Governance of Multinational Enterprises. Journal of Management Studies, no-no.

Gerged, A. M., Cowton, C. J., \& Beddewela, E. S. (2018). Towards Sustainable Development in the Arab Middle East and North Africa Region: A Longitudinal Analysis of Environmental Disclosure in Corporate Annual Reports. Business Strategy and the Environment, 27(4), 572-587.

Greco, G. (2012). The management's reaction to new mandatory risk disclosure: A longitudinal study on Italian listed companies. Corporate Communications: An International Journal, 17(2), 113-137.

Jensen, M. C. (1993). The Modern Industrial Revolution, Exit and the Failure of Internal Control Systems. Journal of Finance, 48(3), 831-880.

Jensen, M. C., \& Meckling, W. H. (1976). Theory of the firm: Managerial behaviour, agency costs and ownership structure. Journal of Financial Economics, 3(4), 305-360.

Jia, C., Ding, S., Li, Y., \& Wu, Z. (2009). Fraud, enforcement action, and the role of corporate governance: Evidence from China. Journal of Business Ethics, 90, 561-576.

Katarachia, A., Pitoska, E., Giannarakis, G., \& Poutoglidou, E. (2018). The drivers of corporate governance disclosure: the case of Nifty 500 Index. International Journal of Law and Management, 60(2), 681-700.

Khan, A., Muttakin, M. B., \& Siddiqui, J. (2013). Corporate governance and corporate social responsibility disclosures: Evidence from an emerging economy. Journal of Business Ethics, 114(2), 207-223.

Linsley, P. M., Shrives, P. J., \& Crumpton, M. (2006). Risk disclosure: An exploratory study of UK and Canadian banks. Journal of Banking Regulation, 7, 268-282. 
Lipton, M. \& Lorsch, J. W. (1992). 'A Modest Proposal for Improved Corporate Governance', Business Lawyer, vol. 48, no. 1, pp. 59-77.

Luo, D. (2016). Changes in Corporate Governance Practice of the Chinese Commercial Banks. The Development of the Chinese Financial System and Reform of Chinese Commercial Banks, 89-113.

Mahadeo, J. D., Soobaroyen, T., \& Oogarah-Hanuman, V. (2012). Board composition and financial performance: Uncovering the effects of diversity in an emerging economy'. Journal of Business Ethics, 105(3), 375-388.

Mansell, S. F. (2013). Capitalism, corporations and the social contract: A critique of stakeholder theory.

Mishra, R. K., \& Jhunjhunwala, S. (2013). Diversity and the effective corporate board. Academic Press.

Norwani, N. M., Mohamad, Z. Z., \& Chek, I. T. (2011). Corporate Governance Failure and Its Impact on Financial Reporting Within Selected Companies. International Journal of Business and Social Science, 2(21).

Ntim, C. G. (2012). Does the South African stock market values independent dual board leadership structure? Economics and Business Letters, 1(1), 35-45.

Ntim, C. G., \& Soobaroyen, T. (2012). Black economic empowerment disclosures: the influence of ownership and board characteristics. Journal of Business Ethics

Ntim, C. G., Lindop, S., \& Thomas, D. A. (2013). Corporate governance and risk reporting in South Africa: A study of corporate risk disclosures in the pre- and post-2007/2 financial crisis periods. International Review of Financial Analysis, 30, 363-383.

Ntim, C. G., Opong, K. K., \& Danbolt, J. (2012a). The Relative Value Relevance of Shareholder versus Stakeholder Corporate Governance Disclosure Policy Reforms in South Africa. Corporate Governance: An International Review, 20(1), 84-105.

Nyombi, C. (2018). The USA as a good comparator for UK in corporate governance. International Journal of Law and Management, 60(1), 135-149.

Oliveira, J., Rodrigues, L. L., \& Craig, R. (2011). Risk-Related Disclosures by Non-Finance Companies: Portuguese Practices and Disclosure Characteristics. Managerial Auditing Journal, 26(9), 817-839.

Pfeffer, J., \& Salancik, G. R. (1978). The External Control of Organizations: A Resource Dependence Perspective. New York: Harper and Row.

Phillips, R. (2011). Stakeholder theory: Impact and prospects. Cheltenham, UK: Edward Elgar.

Raj, B., \& Handley-Schachler, M. (2009). Corporate risk disclosure by UK firms: Trends and determinants. World Review of Entrepreneurship Management and Sustainable Development, 5(3), 224-243.

Reverte, C. (2009). Determinants of corporate social responsibility disclosure ratings by Spanish listed firms. Journal of Business Ethics, 88, 351-366.

Ruiz-Mallorquí, M. V., \& Santana-Martín, D. J. (2011). Dominant institutional owners and firm value. Journal of Banking \& Finance, 35(1), 118-129.

Shultz, S. (2001). The board book: Making your corporate board a strategic force in your company's success. AMACOM/American Management Association.

Srivastava, V., Das, N., \& Pattanayak, J. K. (2018). Corporate governance: mapping the change. International Journal of Law and Management, 60(1), 19-33.

Stuebs, M., \& Sun, L. (2015). Corporate governance and social responsibility. International Journal of Law and Management, 57(1), 38-52.

Suchman, M. C. (1995). Managing legitimacy: Strategic and institutional approaches. Academy of Management Review, 20, 571-606. 
Taylor, G., Tower, G. and Neilson, J. (2010), "Corporate communication of financial risk", Accounting and Finance, Vol. 50, pp. 417-46.

Trinh, T. H., Duyen, T. T., \& Thao, N. T. (2015). The Impact of Corporate Governance on Financial Risk in Vietnamese Commercial Banks. International Journal of Economics and Finance, 7(7), 123.

Vafeas, N., \& Theodorou, E. (1998). The relationship between board structure and firm performance in the UK. The British Accounting Review, 30(4), 383-407.

Van der Walt, N., \& Ingley, C. (2003). Board Dynamics and the Influence of Professional Background, Gender and Ethnic Diversity of Directors. Corporate Governance: An International Review, 11, 218-234.

Walt, N., \& Ingley, C. (2003). Board Dynamics and the Influence of Professional Background, Gender and Ethnic Diversity of Directors. Corporate Governance, 11(3), 218-234. 